\title{
molecules
}

ISSN 1420-3049

www.mdpi.com/journal/molecules

Article

\section{A Facile Asymmetric Synthesis of ( $S$ )-14-Methyl-1-Octadecene, the Sex Pheromone of the Peach Leafminer Moth}

\author{
Tao Zhang ${ }^{1, \dagger}$, Wei-Li Ma ${ }^{1, \dagger}$, Tian-Rui Li ${ }^{1}$, Jia Wu ${ }^{1}$, Jun-Run Wang ${ }^{1}$ and Zhen-Ting Du ${ }^{1,2, *}$
}

1 College of Sciences, Northwest A\&F University Yangling 712100, Shaanxi, China;

E-Mails: fuzitong@163.com (T.Z.); maweili@nwsuaf.edu.cn (W.-L.M.);

litianrui001@gmail.com (T.-R.L.); jiabaobao1991@gmail.com (J.W.); wangjr07@163.com (J.-R.W.)

2 Key Laboratory of Synthetic Chemistry of Natural Substances, Shanghai Institute of Organic

Chemistry, Chinese Academy of Sciences, Shanghai 20032, China

$\dagger$ These authors contributed equally to this work.

* Author to whom correspondence should be addressed; E-Mail: duzt@nwsuaf.edu.cn;

Tel./Fax: +86-29-8709-2226.

Received: 28 March 2013; in revised form: 27 April 2013 / Accepted: 28 April 2013 /

Published: 7 May 2013

\begin{abstract}
An asymmetric synthesis of 14-methyl-1-octadecene, the sex pheromone of the peach leafminer moth has been achieved. The target molecule was synthesized in six linear steps and in $30.3 \%$ overall yield from commercially available hexanoyl chloride, $(S)$-4-benzyloxazolidin-2-one and 1,9-nonanediol. The hexanoyl chloride was connected with (S)-4-benzyloxazolidin-2-one, and with the induction of the chiral oxazolidinone auxiliary, after chiral methylation, LAH reduction and then tosylation gave the chiral key intermediate 5 in high stereoselectivity. 1,9-Nonanediol, was selectively brominated, THP protected and subjected to $\mathrm{Li}_{2} \mathrm{CuCl}_{4}$-mediated $\mathrm{C}-\mathrm{C}$ coupling to afford a $\mathrm{C}_{12}$ intermediate. The target molecule, $(S)$-14-methyl-1-octadecene, was obtained after the two parts were subjected to a second $\mathrm{Li}_{2} \mathrm{CuCl}_{4}$-mediated $\mathrm{C}$-C coupling. Our synthetic approach represents the first time a substrate-control asymmetric synthesis of $(S)$-14-methyl-1-octadecene has been reported.
\end{abstract}

Keywords: 14-methyl-1-octadecene; asymmetric synthesis; peach leafminer moth; (S)-4-benzyloxazolidin-2-one 


\section{Introduction}

Nowadays, there is a sharp conflict between intense agricultural production and environmental issues. We all are facing a big challenge caused by the detrimental effects resulting from traditional agricultural production [1], therefore, there is an urgent need to develop more green production modes, such as the use of environmentally benign, low-dosage sex pheromones to control pests [2,3]. This mode plays an important role in so-called Integrated Pest Management (IPM). The peach leafminer moth, Lyonetia clerkella, is one of the most destructive pests in peach orchards in East Asia. It causes defoliation when the leaves are infested by only a few larvae of this insect and Chinese orchardists use traditional highly toxic pesticides to control it. We envisaged that an ideal way to control it could be by using its sex pheromone to disrupt its mating process and to trap it at a suitable time.

The sex pheromone of peach leafminer was first identified as (S)-14-methyl-1-octadecene (1, Figure 1) by Sugie et al. [4] and syntheses of 1 in racemic form have been achieved by two teams [5,6]. Recently, Ando disclosed an informal synthesis of $( \pm)$-1 through a hard-to-get intermediate [7]. The asymmetric syntheses of 1 were also reported by Mori [8] and Kharisov [9], who both used expensive chiral starting materials. However, the existing synthetic pathways have some drawbacks such as requiring too many chemical operations or lack of cost-effectiveness, so the development of a more economical synthesis of $\mathbf{1}$ in consideration of applying this kind of chemical in the pesticide industry is highly desirable.

Figure 1. Peach leafminer moth and the chemical structure of its sex pheromone.
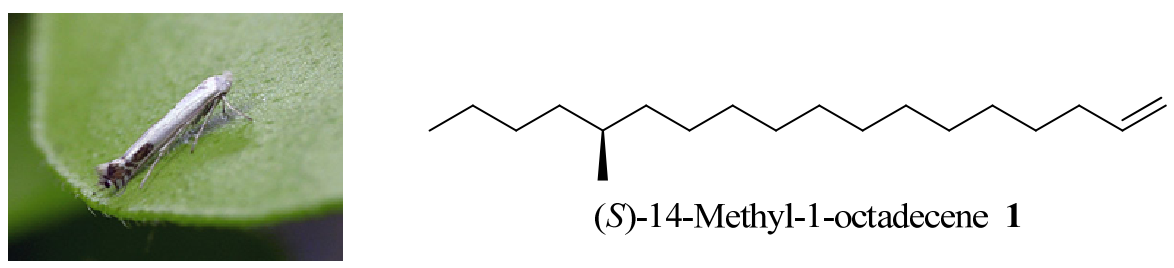

(S)-14-Methyl-1-octadecene 1

Our research group is interested in finding new agrochemicals and lowering the cost of existing lead compounds or pesticides $[3,10]$. We are interested in an efficient and convenient synthesis of sex pheromones through more economical approaches. Herein, we wish to report a synthesis of (S)-14-methyl-1-octadecene (1) from inexpensive starting materials by a substrate-induction strategy.

\section{Results and Discussion}

The retrosynthesis of $\mathbf{1}$ is shown in Scheme 1. First, the molecule was disconnected into a chiral $\mathrm{C}_{7}$ synthon $\mathrm{A} 1$ and $\mathrm{C}_{12}$ moiety. Then the $\mathrm{C}_{12}$ moiety in turn could be disconnected into two parts to be joined through a $\mathrm{Li}_{2} \mathrm{CuCl}_{4}$ mediated $\mathrm{C}-\mathrm{C}$ coupling protocol, a $\mathrm{C}_{9}$ subunit $\mathbf{A 2}$ and an allyl bromide which is highly active in $\mathrm{S}_{\mathrm{N}} 2$ reactions and helpful to apply the strategy.

As shown in Scheme 2, our synthesis commenced with $(S)$-4-benzyloxazolidin-2-one, which is cheap and can be recycled in industry. After deprotonation, it reacted with hexanoyl chloride to give $\mathbf{2}$ in $70 \%$ yield. Compound 2 was deprotonated at $-78{ }^{\circ} \mathrm{C}$ in the presence of a strong base such as LDA, then it was stereoselectively methylated to afford 3 [11-13]. Because of the steric effect of chiral benzyl group in the oxazolidine ring, the methyl groups was directed to the $\beta$-face in d.r. $=1: 50$ and 
$78 \%$ yield. Then the chiral oxazolidine auxiliary was smoothly removed by LAH reduction at $-10{ }^{\circ} \mathrm{C}$. However, in attempting to purify compound $\mathbf{4}$ in the laboratory, this was found to be very laborious and less effective, so the crude 4 was directly treated with $\mathrm{TsCl}$ in pyridine, thus the key intermediate 5 was obtained in 55\% yield in two steps. 9-Bromononan-1-ol was prepared in large quantities from nonane-1,9-diol through selective bromination of the $\alpha, \omega$-diol by a known method reported by Kang et al. [14]. The hydroxyl group of 7 was protected as its tetrahydropyranyl ether in $92 \%$ yield by 3,4-dihydro- $2 \mathrm{H}$-pyran under acidic conditions. Compound $\mathbf{8}$ can be converted into a Grignard reagent, and then this was coupled with allyl bromide under $\mathrm{Li}_{2} \mathrm{CuCl}_{4}$ catalysis to form 9 in $66 \%$ yield $[15,16]$. Afterwards, the THP group was removed in methanol in the presence of 4-methyl-benzenesulfonic acid $[17,18]$. Compound $\mathbf{1 1}$ was produced in $90 \%$ yield after $\mathbf{1 0}$ was subjected to a Corey-Fuji protocol.

Scheme 1. Retrosynthesis of 1.

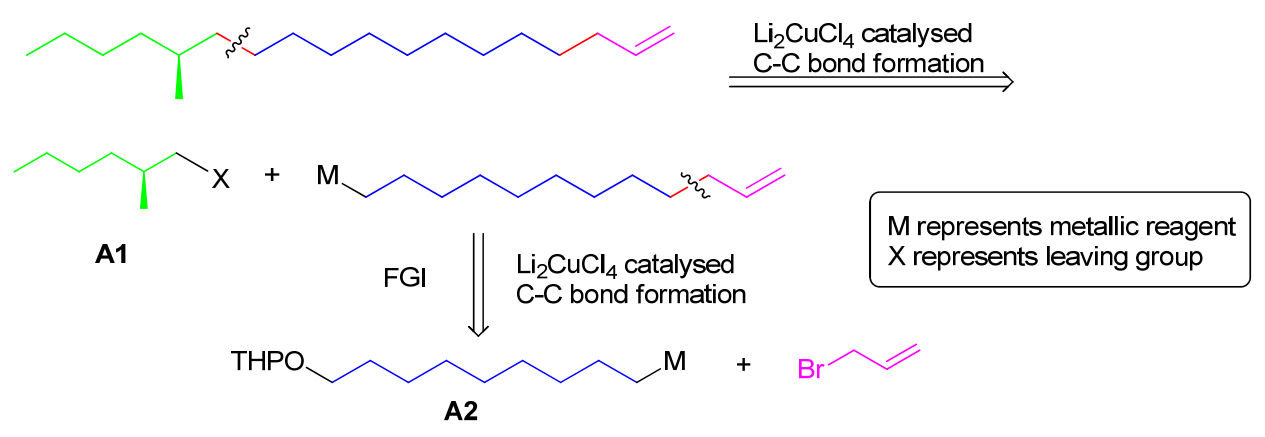

Scheme 2. Synthesis of $(S)$-1.

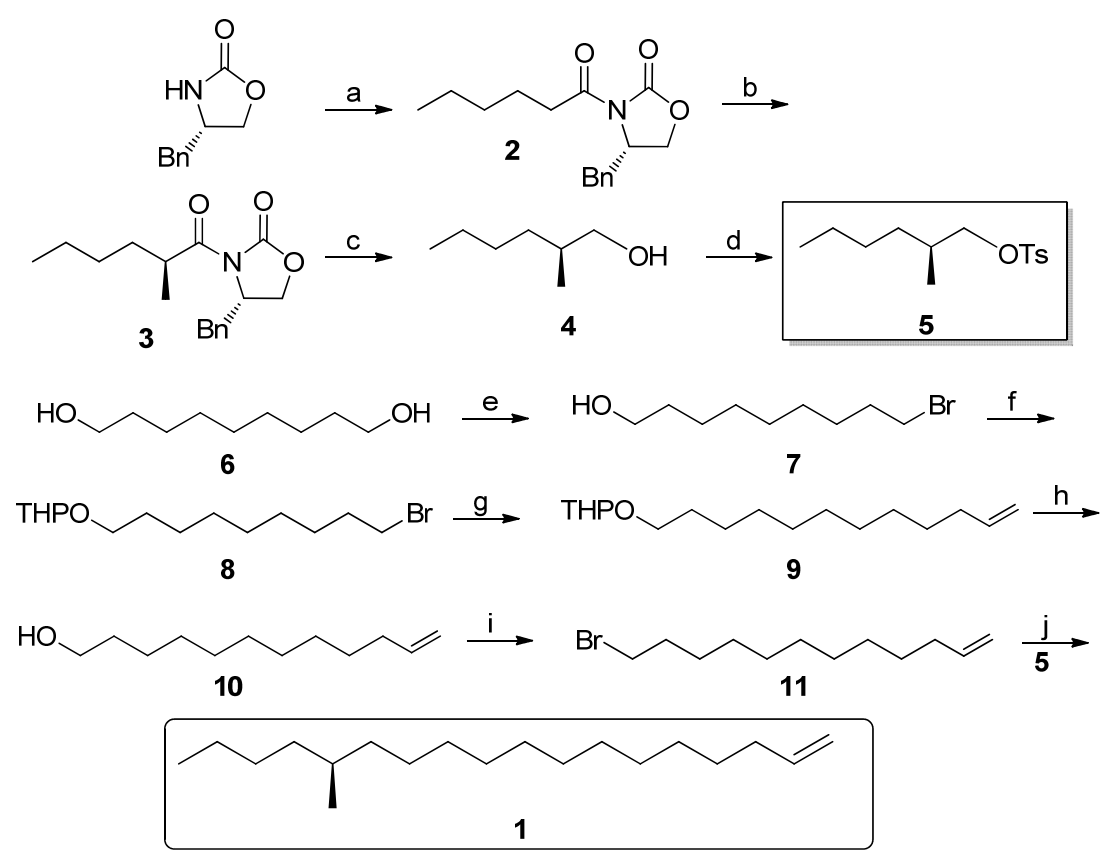

Reagents and conditions: a) $\mathrm{BuLi},-78{ }^{\circ} \mathrm{C}$ then hexanoyl chloride, $70 \%$; b) LDA, $-78{ }^{\circ} \mathrm{C}$, MeI, $78 \%$, d.r. $=1: 50$; c) $\mathrm{LAH},-10{ }^{\circ} \mathrm{C}$; d) TsCl, Pyr., $-10{ }^{\circ} \mathrm{C}, 15 \mathrm{~h}, 55 \%$ for two steps; e) $40 \% \mathrm{HBr}$, toluene, $\mathrm{I}_{2}$, Dean-Stark trap, $80{ }^{\circ} \mathrm{C}, 89 \%$; f) TsOH (cat.), DHP, $\mathrm{CH}_{2} \mathrm{Cl}_{2} 0{ }^{\circ} \mathrm{C}$ - r. t. $92 \%$; g) $\mathrm{Mg}$ then $\mathrm{Li}_{2} \mathrm{CuCl}_{4}$, allylic bromide, $0{ }^{\circ} \mathrm{C}$ to reflux, $66 \%$; h) $\mathrm{CH}_{3} \mathrm{OH} / \mathrm{H}_{2} \mathrm{O}$, PPTS (cat.), reflux 3h, 96\%; i) $\mathrm{PPh}_{3}, \mathrm{CBr}_{4}, \mathrm{CH}_{2} \mathrm{Cl}_{2}, 90 \%$; j) $\mathrm{Mg}$ then $\mathrm{Li}_{2} \mathrm{CuCl}_{4}, 65 \%$. 
With compound $\mathbf{1 1}$ in hand, it was converted into the corresponding Grignard reagent and coupled with 5 in the presence of $\mathrm{Li}_{2} \mathrm{CuCl}_{4}$ to afford $(S)-1$ in $65 \%$ yield. Thus, the asymmetric total synthesis of $(S)-1$ in an overall yield of $30.3 \%$ was achieved in six linear steps. Compared with other asymmetric synthesis of the target, our synthesis is apparently more cost-effective, even if the chiral oxazolidinone auxiliary were not recycled.

\section{Experimental}

\section{General}

The ${ }^{1} \mathrm{H}-\mathrm{NMR}$ and ${ }^{13} \mathrm{C}-\mathrm{NMR}$ data were recorded in $\mathrm{CDCl}_{3}$ solution with Bruker NMR spectrometers (DRX 500, AM 300) if not noted otherwise. The chemical shifts are measured relative to TMS $(\delta=0)$ or chloroform ( $\delta=7.26$ ) and the coupling $J$ is expressed in Hertz. Mass spectra were recorded on a Thermo Scientific TSQ Quantum Access MAX mass spectrometer (ESI, positive or negative). Standard flash chromatography was employed to purify the crude reaction mixture using 200-300 mesh silica gel (Tsingdao Ocean Company, Tsingdao, China) under a positive nitrogen pressure. Tetrahydrofuran (THF) and diethyl ether were freshly distilled from lithium aluminium hydride under an argon atmosphere. Dichloromethane, hexane and toluene were freshly distilled from calcium hydride under argon.

(S)-4-Benzyl-3-hexanoyloxazolidin-2-one (2). At $-78^{\circ} \mathrm{C}$, to a solution of $(S)$-4-benzyloxazolidin-2-one $(5.32 \mathrm{~g}, 0.03 \mathrm{~mol})$ in anhydrous THF $(50 \mathrm{~mL})$ was added BuLi $(0.036 \mathrm{~mol})$, then freshly distilled hexanoyl chloride $(4.63 \mathrm{~g}, 0.033 \mathrm{~mol})$ in THF $(25 \mathrm{~mL})$ was added after half an hour. The mixture was gradually warmed to $25^{\circ} \mathrm{C}$ and maintained for $12 \mathrm{~h}$. After completion, the reaction was quenched by addition of saturated aqueous $\mathrm{NH}_{4} \mathrm{Cl}$, and the volatiles were evaporated. The residue was extracted with ethyl acetate $(100 \mathrm{~mL} \times 3)$, and the combined organic layers were washed with dilute $\mathrm{NaOH}$ and brine, and dried over anhydrous $\mathrm{MgSO}_{4}$. Then the extract was evaporated, and purified by column chromatography (15-25\% gradient, EtOAc-hexane) to give 2 as a yellowish oil (5.78 g, 70\%). $[\alpha]_{D}^{25}=+97.6^{\circ}$ (c 0.36, MeOH); ${ }^{1} \mathrm{H}-\mathrm{NMR}\left(500 \mathrm{MHz}, \mathrm{CDCl}_{3}\right): 0.90$ (br s, 3H), 1.34 (br s, 4H), 1.67 (br s, 2H), 2.73-2.77 (m, 1H), 2.84-2.93 (m, 2H), $3.22(\mathrm{~d}, J=13.3,1 \mathrm{H}), 4.10(\mathrm{~s}, 2 \mathrm{H}), 4.62(\mathrm{~s}, 1 \mathrm{H})$, 7.17-7.28 (m,5H); ${ }^{13} \mathrm{C}-\mathrm{NMR}\left(125 \mathrm{MHz}, \mathrm{CDCl}_{3}\right): 13.9,22.4,23.9,31.3,35.4,37.8,55.0,66.1,127.2$, $128.8,129.4,135.5,153.4,173.2$.

(S)-4-Benzyl-3-((S)-2-methylhexanoyl)oxazolidin-2-one (3). To a cooled $\left(-78{ }^{\circ} \mathrm{C}\right)$ solution of LDA $(0.051 \mathrm{~mol})$ was added a solution of compound $2(11.7 \mathrm{~g}, 43 \mathrm{mmol})$ in THF $(90 \mathrm{~mL})$. After $2 \mathrm{~h}$, dry MeI (13.3 mL, $0.213 \mathrm{~mol})$ was introduced through a dropping funnel at this temperature. The reaction mixture was allowed to stir at $-78^{\circ} \mathrm{C}$ for $3 \mathrm{~h}$ before being warmed to $25^{\circ} \mathrm{C}$ and maintained overnight. The reaction was quenched with saturated aqueous $\mathrm{NH}_{4} \mathrm{Cl}(50 \mathrm{~mL})$, and the aqueous layer was extracted with three $50 \mathrm{~mL}$ portions of EtOAc. The combined organic extracts were dried $\left(\mathrm{MgSO}_{4}\right)$, concentrated in vacuo, and chromatographed (15-25\% gradient, EtOAc-hexane) to provide of pure 3 (9.7 g, 78\%): $[\alpha]_{D}^{25}=+104.4^{\circ}(\mathrm{c} 0.28, \mathrm{MeOH}) ;{ }^{1} \mathrm{H}-\mathrm{NMR}\left(500 \mathrm{MHz}, \mathrm{CDCl}_{3}\right) 0.89(\mathrm{t}, J=6.8,3 \mathrm{H}), 1.22$ $(\mathrm{d}, J=6.9,3 \mathrm{H}), 1.27-1.40(\mathrm{~m}, 4 \mathrm{H}), 1.40-1.44(\mathrm{~m}, 1 \mathrm{H}), 1.72-1.76(\mathrm{~m}, 1 \mathrm{H}), 2.77(\mathrm{dd}, J=13.3,9.6$, $1 \mathrm{H}), 3.26(\mathrm{dd}, J=13.3,2.9,1 \mathrm{H}), 3.38-3.73(\mathrm{~m}, 1 \mathrm{H}), 4.15-4.21(\mathrm{~m}, 2 \mathrm{H}), 4.65-4.69(\mathrm{~m}, 1 \mathrm{H}), 7.21-7.34$ 
(m, 5H); ${ }^{13} \mathrm{C}-\mathrm{NMR}\left(125 \mathrm{MHz}, \mathrm{CDCl}_{3}\right): 14.0,17.4,22.7,29.5,33.2,37.7,37.9,55.4,66.0,127.3$, 128.9, 129.5, 135.4, 153.1, 177.4. ESI-MS: $m / z: 290(\mathrm{M}+\mathrm{H}), 276$.

(S)-2-Methylhexyl 4-methylbenzenesulfonate (5). To a cooled $\left(0{ }^{\circ} \mathrm{C}\right)$ suspension of $\mathrm{LiAlH}_{4}(606 \mathrm{mg}$, $16 \mathrm{mmol})$ in anhydrous THF $(20 \mathrm{~mL})$ was added a solution of the imide 3 (1.4 g, $5 \mathrm{mmol})$ in THF $(30 \mathrm{~mL})$ over a $15 \mathrm{~min}$ period. After an additional $30 \mathrm{~min}$ of stirring, the cold $\left(0{ }^{\circ} \mathrm{C}\right)$ reaction was slowly quenched with water $(0.6 \mathrm{~mL})$, then $10 \%$ aqueous $\mathrm{NaOH}(1.2 \mathrm{~mL})$ and water $(1.8 \mathrm{~mL})$ to precipitate the aluminum salts, which were then filtered. The filtrate was dried $\left(\mathrm{MgSO}_{4}\right)$, and the solution was concentrated in vacuo. Because of the volatility of the product, the crude product was used directly for the next step. To the cooled $\left(-10^{\circ} \mathrm{C}\right)$ solution of the above alcohol 4 in pyridine $(20 \mathrm{~mL})$ was added 4-methylbenzene-1-sulfonyl chloride (1.0 g, $5.1 \mathrm{mmol})$. After the solution was stirred an additional $30 \mathrm{~min}$ at $-10{ }^{\circ} \mathrm{C}$, the reaction mixture was slowly warmed to $20{ }^{\circ} \mathrm{C}$ for an additional $30 \mathrm{~min}$ period. The reaction was then quenched with brine $(30 \mathrm{~mL})$, and the aqueous layer was extracted with three $30 \mathrm{~mL}$ portions of $\mathrm{CH}_{2} \mathrm{Cl}_{2}$. The combined organic extracts were washed with brine, diluted $\mathrm{HCl}$ and saturated aqueous $\mathrm{CuSO}_{4}$ and dried over $\mathrm{MgSO}_{4}$, concentrated in vacuo, and chromatographed (10\% EtOAc-hexane) to provide pure $5(0.75 \mathrm{~g}, 55 \%$ for two steps $)[\alpha]_{D}^{25}=-2.6^{\circ}$ (c 1.67, $\mathrm{CH}_{2} \mathrm{Cl}_{2}$ ); ${ }^{1} \mathrm{H}-\mathrm{NMR}\left(500 \mathrm{MHz}, \mathrm{CDCl}_{3}\right) 0.85$ (t, $\left.J=7.0,3 \mathrm{H}\right), 0.87$ (d, $\left.J=6.7,3 \mathrm{H}\right), 1.09-1.13$ $(\mathrm{m}, 2 \mathrm{H}), 1.20-1.25(\mathrm{~m}, 4 \mathrm{H}), 1.73-1.79(\mathrm{~m}, 1 \mathrm{H}), 2.45(\mathrm{~s}, 3 \mathrm{H}), 3.80(\mathrm{dd}, J=6.5,6.4,1 \mathrm{H}), 3.88(\mathrm{dd}$, $J=5.6,5.7,1 \mathrm{H}), 7.34(\mathrm{~d}, J=8.1,2 \mathrm{H}), 7.787(\mathrm{~d}, J=8.1,2 \mathrm{H})$. ESI-MS: $m / z: 270(\mathrm{M}+\mathrm{H}), 173,155,91$.

9-Bromononan-1-ol (7). A mixture of nonane-1,9-diol 6 (24 g, $0.15 \mathrm{~mol}$ ), a catalytic amount of iodine $(0.5 \mathrm{~g}, 2 \mathrm{mmol})$ and $40 \% \mathrm{HBr}(33 \mathrm{~mL})$ in toluene $(240 \mathrm{~mL})$ was heated to reflux and the water formed was separated continuously for $30 \mathrm{~h}$. Then the mixture was washed successively with water, aqueous $\mathrm{NaOH}, \mathrm{HCl}$, water and brine. The organic phase was concentrated in vacuo, and chromatographed $(10 \%$ EtOAc-hexane) to give $30 \mathrm{~g}$ of pure 7 as a colorless oil in $89 \%$ yield. ${ }^{1} \mathrm{H}-\mathrm{NMR}\left(500 \mathrm{MHz}, \mathrm{CDCl}_{3}\right)$ $1.31-1.36(\mathrm{~m}, 8 \mathrm{H}), 1.41-1.43(\mathrm{~m}, 2 \mathrm{H}), 1.49$ (br s, 1H), 1.53-1.59 (m, 2H), 1.82-1.88 (m, 2H), 3.41 $(\mathrm{t}, J=6.85,2 \mathrm{H}), 3.63(\mathrm{t}, J=6.62,2 \mathrm{H})$. ESI-MS: $m / z: 223(\mathrm{M}+\mathrm{H}), 207$.

2-((9-Bromononyl)oxy)tetrahydro-2H-pyran (8). To a solution of 9-bromononan-1-ol (7, $25 \mathrm{~g}$, $0.112 \mathrm{~mol})$ in anhydrous $\mathrm{CH}_{2} \mathrm{Cl}_{2}(150 \mathrm{~mL})$ was added 4-methylbenzenesulfonic acid $(0.3 \mathrm{~g})$ and freshly distilled 3, 4-dihydro-2 $\mathrm{H}$-pyran $(11.24 \mathrm{~mL}, 0.123 \mathrm{~mol})$ in $\mathrm{CH}_{2} \mathrm{Cl}_{2}(10 \mathrm{~mL})$, at $0{ }^{\circ} \mathrm{C}$. After addition, the mixture was allowed to stir for $5 \mathrm{~h}$ at room temperature and monitored by TLC. Then the solution was diluted by addition of another portion of $\mathrm{CH}_{2} \mathrm{Cl}_{2}(150 \mathrm{~mL})$ and then the reaction mixture was washed with saturated aqueous $\mathrm{NaHCO}_{3}$ and brine, dried over anhydrous $\mathrm{MgSO}_{4}$ and then concentrated in vacuo and chromatographed to afford $31.6 \mathrm{~g}$ (92\% yield) of pure $\mathbf{8}$ as a colorless oil. ${ }^{1} \mathrm{H}-\mathrm{NMR}\left(500 \mathrm{MHz}, \mathrm{CDCl}_{3}\right.$ ): 1.36 (br s, 8H), 1.36-1.42 (m, 2H), 1.50-1.60 (m, 6H), 1.69-1.71 (m, 1H), 1.80-1.88 (m, 3H), 3.36-3.42 (m, 3H), 3.48-3.51 (m, 1H), 3.36-3.75 (m, 1H), 3.85-3.89 (m, 1H), $4.57(\mathrm{t}, J=3.4,1 \mathrm{H}) ;{ }^{13} \mathrm{C}-\mathrm{NMR}\left(125 \mathrm{MHz}, \mathrm{CDCl}_{3}\right)$ 19.7, 25.5, 26.2, 28.2, 28.7, 29.4, 29.4, 30.8, 32.8, 34.0, 62.3, 67.6, 98.8. EI-MS: $m / z: 305(\mathrm{M}-\mathrm{H})$.

2-(Dodec-11-en-1-yloxy)tetrahydro-2H-pyran (9). Under a nitrogen atmosphere at $20{ }^{\circ} \mathrm{C}, \mathrm{Mg}$ turnings $(56 \mathrm{mmol}, 1.37 \mathrm{~g})$, a catalytic amount of iodine and anhydrous THF $(25 \mathrm{~mL})$ were placed in a dry $500 \mathrm{~mL}$ three-necked round-bottomed flask equipped with a condenser and a dropping funnel. A solution of 
compound 8 (13 g, $42 \mathrm{mmol})$ in THF $(150 \mathrm{~mL})$ was added dropwise to the above mixture (approx. $20 \mathrm{~min}$ ). Then the mixture was allowed to reflux for another $5 \mathrm{~h}$. Another dry $500 \mathrm{~mL}$ three-necked round-bottomed flask was charged with allyl bromide $(84 \mathrm{mmol})$, NMP $(4 \mathrm{~mL})$ and $\mathrm{Li}_{2} \mathrm{CuCl}_{4}(0.3 \mathrm{M}$ in THF, $4 \mathrm{~mL}$ ). The above Grignard reagent was transferred to this flask through a double-ended needle with stirring. After transfer, the reaction mixture was warmed to $85{ }^{\circ} \mathrm{C}$ for $12 \mathrm{~h}$. After cooling, the reaction mixture was quenched by dropwise addition of saturated aqueous $\mathrm{NH}_{4} \mathrm{Cl}$ solution. The THF was recovered on a rotavapor and the residue was extracted with ethyl acetate $(100 \mathrm{~mL} \times 3)$. The combined organic extracts were dried $\left(\mathrm{MgSO}_{4}\right)$, concentrated in vacuo, and chromatographed (15-25\% gradient, EtOAc-hexane) to provide $7.5 \mathrm{~g}(66 \%)$ of pure 9 as a colorless oil. ${ }^{1} \mathrm{H}-\mathrm{NMR}(500 \mathrm{MHz}$, $\left.\mathrm{CDCl}_{3}\right) 1.27-1.30(\mathrm{~m}, 10 \mathrm{H}), 1.40-1.57(\mathrm{~m}, 4 \mathrm{H}), 1.58-1.94(\mathrm{~m}, 8 \mathrm{H}), 1.95-2.13(\mathrm{~m}, 2 \mathrm{H}), 3.37-3.38(\mathrm{~m}$, $2 \mathrm{H}), 3.68-3.73(\mathrm{~m}, 2 \mathrm{H}), 4.57(\mathrm{t}, J=6.8,1 \mathrm{H}), 4.91-4.96(\mathrm{~m}, 1 \mathrm{H}), 5.01-5.23(\mathrm{~m}, 1 \mathrm{H}), 5.74-5.99(\mathrm{~m}$, $1 \mathrm{H}),{ }^{13} \mathrm{C}-\mathrm{NMR}\left(125 \mathrm{MHz}, \mathrm{CDCl}_{3}\right)$ some signals were overlapped. 139.2, 114.1, 98.8, 67.6, 62.2, 31.8, 30.8, 29.8, 29.6, 29.5, 29.3, 26.2, 25.5. EI-MS: $m / z: 267$ (M-H), 191.

Dodec-11-en-1-ol (10). To a solution of compound $9(7.0 \mathrm{~g}, 26 \mathrm{mmol})$ in $\mathrm{MeOH}(100 \mathrm{~mL})$ was added a catalytic amount of PPTS with stirring. Then the reaction mixture was heated to $50{ }^{\circ} \mathrm{C}$ overnight and monitored by TLC. After completion, the methanol was removed on a rotavapor, And the residue was purified by column chromagraphy (15-25\% gradient, EtOAc-hexane) to give dodec-11-en-1-ol (4.3 g, $96 \%$ yield) as a colorless oil. ${ }^{1} \mathrm{H}-\mathrm{NMR}\left(500 \mathrm{MHz} \mathrm{CDCl}_{3}\right) 1.27-1.30(\mathrm{~m}, 14 \mathrm{H}) 1.52-1.59(\mathrm{~m}, 2 \mathrm{H})$, 2.01-2.06 (m, 2H), 2.10 (br s, 1H), 3.62 (t, $J=6.6,2 \mathrm{H}), 4.92$ (dd, $J=12.1,1.6,1 \mathrm{H}), 4.98$ (dd, $J=17.1,1.6,1 \mathrm{H}), 5.75-5.83(\mathrm{~m}, 1 \mathrm{H}) ;{ }^{13} \mathrm{C}-\mathrm{NMR}\left(125 \mathrm{MHz}, \mathrm{CDCl}_{3}\right)$ 139.2, 114.2, 62.90, 33.8, 32.7, 31.9, 29.7, 29.5, 29.4, 29.3, 29.1, 28.9. EI-MS: $m / z$ : 184 .

12-Bromododec-1-ene (11). A dry $250 \mathrm{~mL}$ three-necked round-bottomed flask was charged with $\mathrm{PPh}_{3}$ (14.7 g, $56 \mathrm{mmol})$, dichloromethane $(80 \mathrm{~mL})$ and $\mathrm{CBr}_{4}(22.2 \mathrm{~g}, 67 \mathrm{mmol})$ and the mixture was allowed to stir for $20 \mathrm{~min}$. To the above solution was added compound $\mathbf{1 0}$ portionwise at $-10{ }^{\circ} \mathrm{C}$. After completion, the volatiles were removed on a rotavapor, and the residue was purified by column chromagraphy directly to give 12-bromododec-1-ene $\left(\mathbf{1 1}, 90 \%\right.$ yield) as a colorless oil. ${ }^{1} \mathrm{H}-\mathrm{NMR}$ $\left(500 \mathrm{MHz}, \mathrm{CDCl}_{3}\right) 1.30-1.35(\mathrm{~m}, 14 \mathrm{H}) 1.35-1.45(\mathrm{~m}, 2 \mathrm{H}), 1.83-1.90(\mathrm{~m}, 1 \mathrm{H}), 2.02-2.08(\mathrm{~m}, 1 \mathrm{H})$, $3.62(\mathrm{t}, J=6.8,2 \mathrm{H}), 4.93-4.96(\mathrm{~m}, 1 \mathrm{H}), 5.00(\mathrm{ddd}, J=21.4,4.6,1.6,1 \mathrm{H}), 5.75-5.83(\mathrm{~m}, 1 \mathrm{H})$; ${ }^{13} \mathrm{C}-\mathrm{NMR}\left(125 \mathrm{MHz}, \mathrm{CDCl}_{3}\right.$ ) 139.2, 114.1, 33.9, 33.8, 32.7, 31.9, 29.7, 29.5, 29.4, 29.3, 29.1, 28.9. EI-MS: $m / z: 247$ (M-H), 245, 191, 189.

(S)-14-Methyloctadec-1-ene (1). Under nitrogen atmosphere at $20{ }^{\circ} \mathrm{C}, \mathrm{Mg}$ turnings $(0.2 \mathrm{~g}, 8.4 \mathrm{mmol})$, a catalytic amount of iodine, and anhydrous THF $(5 \mathrm{~mL})$ were placed in a dry $250 \mathrm{~mL}$ three-necked round-bottomed flask equipped with a condenser and a dropping funnel. A solution of compound 11 ( $1.6 \mathrm{~g}, 6.5 \mathrm{mmol})$ in THF $(50 \mathrm{~mL})$ was added dropwise to the above mixture (approx. $20 \mathrm{~min})$. Then the mixture was allowed to reflux for another $5 \mathrm{~h}$. Another dry $500 \mathrm{~mL}$ three-necked round-bottomed flask was charged with the chiral intermediate 5 (1.8 g, $6.5 \mathrm{mmol}), \mathrm{NMP}(2 \mathrm{~mL})$ and $\mathrm{Li}_{2} \mathrm{CuCl}_{4}(0.3 \mathrm{M}$ in THF, $2 \mathrm{~mL}$ ). The above Grignard reagent was transferred to this flask through a double-ended needle with stirring. After transfer, the reaction mixture was warmed to $85{ }^{\circ} \mathrm{C}$ for 3 days. After cooling, the reaction mixture was quenched by dropwise addition of saturated aqueous $\mathrm{NH}_{4} \mathrm{Cl}$ solution. 
The THF was recovered on a rotavapor and the residue was extracted with ethyl acetate $(100 \mathrm{~mL} \times 3)$. The combined organic extracts were dried $\left(\mathrm{MgSO}_{4}\right)$, concentrated in vacuo, and chromatographed to provide $0.8 \mathrm{~g}(65 \%)$ of pure 1 as a colorless oil. Colorless liquid, $[\alpha]_{D}^{25}=+1.17^{\circ}$ (c 1.82, $n$-hexane). ${ }^{1} \mathrm{H}-\mathrm{NMR}\left(300 \mathrm{MHz}, \mathrm{CDCl}_{3}\right): 6.05-5.83(1 \mathrm{H}, \mathrm{m}), 5.03-4.90(2 \mathrm{H}, \mathrm{m}), 2.08-2.00(2 \mathrm{H}, \mathrm{m}), 1.57-1.09$ $(27 \mathrm{H}, \mathrm{m}), 0.93(6 \mathrm{H}, \mathrm{m}) .{ }^{13} \mathrm{C}-\mathrm{NMR}\left(75 \mathrm{MHz} \mathrm{CDCl}_{3}\right)$ : 139.3, 114.1, 41.6, 35.2, 34.6, 33.8, 31.9, 29.7, 29.6, 29.5, 29.3, 29.17, 29.0, 22.7, 14.1. EI-MS: $m / z$ : $266\left(\mathrm{M}^{+}, 3 \%\right), 43$ (100\%).

\section{Conclusions}

In summary, we have completed an asymmetric total synthesis of $(S)$-14-methyl-1-octadecene, the sex pheromone of the peach leafminer moth, by chiral oxazolidinone auxiliary induced methylation and $\mathrm{Li}_{2} \mathrm{CuCl}_{4}$ catalytic cross coupling reactions. Compared with the reported syntheses, this process has several advantages such as high yield, easy operation and cost-effectiveness. This may be helpful to develop a new generation of affordable pesticides to control peach leafminer moths for Chinese orchardists in the future.

\section{Supplementary Materials}

Supplementary materials can be accessed at: http://www.mdpi.com/1420-3049/18/5/5201/s1.

\section{Acknowledgments}

Financial support from the open funding of Key Laboratory of Synthetic Chemistry of Natural Substances of SIOC as well as the National Natural Science Foundation of China (31270388) is greatly appreciated. We are grateful to Special Fund for Forestry Scientific Research in Public Interest (200904004) for partial support of this work.

\section{Conflict of Interest}

The authors declare no conflict of interest.

\section{References}

1. Anderies, J.; Ryan, P.; Walker, B. Loss of Resilience, Crisis, and Institutional Change: Lessons from an intensive agricultural system in southeastern australia. Ecosystems 2006, 9, 865-878.

2. Petroski, R.J.; Tellez, M.R.; Behle, R.W. Semiochemicals in Pest and Weed Control; American Chemical Society: Washington, DC, USA, 2005.

3. Zhang, T.; Feng, J.; Cai, C.; Zhang, X. Synthesis and field test of three candidates for soybean pod borer's sex pheromone Nat. Prod. Comm. 2011, 9, 1323-1326.

4. Sugie, H.; Tamaki, Y.; Sato, R.; Kumakura, M. Sex pheromone of the peach leafminer moth, lyonetia clerkella: Isolation and identification. Appl. Entomol. Zool. 1984, 19, 323-330.

5. Manabe, Y.; Minamikawa, J., II; Otsubo, J.I.; Tamaki, Y. Improved synthesis of 14-methyl-1octadecene, the sex pheromone of the peach leafminer Moth. Agric. Biol. Chem. 1985, 49, 1205-1206. 
6. Akira, Y.; Takehiko, F. Convenient synthesis of racemic 14-methy-1-octadecene, sex pheromone of the peach leafminor Moth. Agric. Biol. Chem. 1989, 53, 1183-1184.

7. Taguri, T.; Yamakawa, R.; Adachi, Y.; Mori, K.; Ando, T. Improved synthesis of three methyl-branched pheromone components produced by the female lichen moth. Biosci. Biotechnol. Biochem. 2010, 74, 119-124.

8. Mori, K.; Kato, M. Pheromone syntheses, LXXVII. New synthesis of the enantiomers of 14-methyl-1-octadecene, the pheromone of Lyonetia clerkella L. Liebigs Ann. Chem. 1985, 2083-2087.

9. Kharisov, R.Y.; Latypova, E.R.; Talipov, R.F.; Muslukhov, R.R.; Ishmuratov, G.Y.; Tolstikov, G.A. (R)-4-Menthenone in the synthesis of optically pure sex pheromone of the peach leafminer moth (Lyonetia clerkella). Russ. Chem. Bull. 2003, 52, 2267-2269.

10. Du, Z.T.; Si, C.M.; Li, Y.Q.; Wang, Y.; Lu, J. Improved synthesis of 5-substituted $1 H$-tetrazoles via the $3+2$ cycloaddition of nitriles and sodium azide catalyzed by silica sulfuric acid. Int. J. Mol. Sci. 2012, 13, 4696-4703.

11. De Joarder, D.; Jennings, M.P. Convergent enantioselective syntheses of two potential C25-C40 subunits of (-)-caylobolide A. Tetrahedron Lett. 2011, 52, 5124-5127.

12. Decicco, C.P.; Grover, P. Total asymmetric synthesis of the potent immunosuppressive marine natural product microcolin A. J. Org. Chem. 1996, 61, 3534-3541.

13. Lan, H.Q.; Ruan, Y.P.; Huang, P.Q. The first enantioselective synthesis of cytotoxic marine natural product palau'imide and assignment of its C-20 stereochemistry. Chem. Commun. 2010, 46, 5319-5321.

14. Kang, S.K.; Kim, W.S.; Moon, B.H. An effective method for the preparation of $\omega$-bromoalkanols from $\alpha, \omega$-diols. Synthesis 1985, 1161-1162.

15. Tamura, M.; Kochi, J. Coupling of Grignard reagents with organic halides. Synthesis 1971, 303-305.

16. Tamura, M.; Kochi, J.K. Copper-catalyzed coupling of Grignard reagents and alkyl halides in tetrahydrofuran solutions. J. Organomet. Chem. 1972, 42, 205-228.

17. Crouch, R.D.; Mehlmann, J.F.; Herb, B.R.; Mitten, J.V.; Dai, H.G. Selective conversion of enol ethers into alcohols in the presence of alkenes using $\mathrm{Hg}(\mathrm{OAc})_{2}-\mathrm{NaBH}_{4}$. Synthesis 1999, 559-561.

18. Quinn, K.J.; Smith, A.G.; Cammarano, C.M. Convergent total synthesis of squamostolide. Tetrahedron 2007, 63, 4881-4886.

Sample Availability: Samples of the compounds 1-10 are available from the authors.

(C) 2013 by the authors; licensee MDPI, Basel, Switzerland. This article is an open access article distributed under the terms and conditions of the Creative Commons Attribution license (http://creativecommons.org/licenses/by/3.0/). 